\title{
KEBUDAYAAN DALAM ISLAM: MENCARI MAKNA DAN HAKEKAT KEBUDAYAAN ISLAM
}

\author{
Mustopa \\ IAIN Syekh Nurjati Cirebon (amustopa10@yahoo.com)
}

\begin{abstract}
Islam as a religion that puts reason in a very respectable position, so that Islam encourages its people to always use their minds. With reason, human has diverification from other God's creatures. By reason, humans have also reached a high culture and civilization. Therefore humans are referred as civilized and civilized beings. Thus, it is true that Islam is a religion that upholds culture and civilization. Therefore it is not surprising that Muslims have reached the golden age by being in the top position in civilization and culture. Even the classical era been a historical witness of the existence of Muslims as the most advanced people in the field of culture and civilization on earth.
\end{abstract}

Keywords: Keywords: Islam, Culture, and Islamic Culture

\begin{abstract}
Abstrak
Islam sebagai agama yang memposisikan akal pada posisi yang sangat terhormat, sehingga dengan demikian islam menganjurkan umatnya untuk selalu menggunakan akalnya. Dengan akal manusia berbeda dengan makhluk-makhluk Allah yang lainnya. Dengan akal pula manusia telah mencapai kebudayaan dan peradaban yang sangat tinggi. Karena itu manusia disebut sebagai makhluk yang berbudaya dan berperadaban. Dengan demikian, adalah benar jika Islam merupakan agama yang menjunjung tinggi kebudayaan dan peradaban. Karena itu tidaklah heran jika umat islam pernah mencapai masa keemasan dengan berada pada posisi puncak dalam peradaban dan kebudayaan. Bahka zaman klasik menjadi saksi sejarah tentang keberadaan umat Islam sebagai umat yang paling maju dalam bidang kebudayaan dan peradaban di muka bumi ini.
\end{abstract}

Kata Kunci: Islam, Kebudayaan, dan Kebudayaan Islam

\section{A. Pendahuluan}

Allah telah menciptakan
manusia dengan memberinya
anugerah yang tidak pernah
diberikan kepada makhluk lainnya.
Karena itu, manusia adalah makhluk
Allah, yang diciptakan di dunia
sebagai khalifah. Manusia lahir,
hidup dan berkembang di dunia,
sehingga disebut juga sebagai
makhluk duniawi. Sebagai makhluk
duniawi sudah barang tentu
bergumul dan bergulat dengan dunia,

terhadap segala segi, masalah dan tantangan-tantangannya, dengan menggunakan budi dan dayanya serta menggunakan segala kemampuannya baik yang bersifat cipta, rasa maupun karsa.

Hal ini menunjukkan bahwa hubungan manusia dengan dunia itu tidaklah selalu diwujudkan dalam sikap pasif, pasrah dan menyesuaikan diri dengan tuntutan lingkungannya. Tetapi justeru harus diwujudkan dalam sikap aktif, 
memanfaatkan lingkungannya untuk kepentingan hidup dan kehidupannya. Dari hubungan yang bersifat aktif itu tumbuhlah kebudayaan. ${ }^{1}$ Dengan melalui kebudayaan inilah eksistensi suatu entitas, masyarakat atau bangsa dapat dikenali.

\section{B. Kebudayaan dan Islam}

1. Kebudayaan

Dalam literatur antropologi, terdapat tiga istilah yang dapat semakna dengan kebudayaan. Terma kultur berasal dari bahasa Latin, yaitu dari kata culture (kata kerja cob, colere). Arti kultur adalah memelihara, mengerjakan, atau mengelola. Kemudian, kebudayaan dimaknai sebagai daya dan kegiatan manusia untuk mengelola dan mengubah alam. Istilah yang kedua adalah sivilisasi. Sivilisasi berasal dari kata Latin, yaitu civis yang artinya adalah warga negara (civitas $=$ negara kota atau kewarganegaraan). ${ }^{2} \quad$ menjelaskan bahwa sivilisasi berhubungan dengan kehidupan kota yang lebih progresif dan lebih halus. Dalam bahasa

${ }^{1}$ Tadjab, dkk., Dimensi-Dimensi Studi Islam, (Surabaya: Karya Aditama, 1999), hlm. 306.

2 S. Takdir Alisyahbana (1986: 206), sebagaimana dikutip oleh Koko Abdul Kodir, Metodologi Studi Islam, (Bandung: Pustaka Setia, 2012), hlm. 80.
Indonesia, peradaban dianggap sepadan dengan kata budaya. ${ }^{3}$

Terkait dengan kebudayaan, maka arti dan ulasan makna yang terkandung dalam istilah kebudayaan banyak dikaji oleh para ahli. Definisi kebudayaan menurut Koentjaraningrat adalah keseluruhan dari kelakuan dan hasil kelakuan manusia yang teratur oleh tata kelakuan yang harus didapatnya dengan belajar dan yang semuanya tersusun dalam kehidupan masyarakat. $^{4}$ Parsudi Suparlan menjelaskan, bahwa kebudayaan adalah merupakan serangkaian aturan pertunjukan, resep, rencana, dan strategi yang terdiri atas serangkaian model kognitif yang dimiliki manusia, dan digunakannya secara selektif dalam menghadapi lingkungannya sebagaimana terwujud dalam tingkah laku dan tindakan-tindakannya. ${ }^{5}$ Sementara itu, S. Takdir Alisjahbana berpendapat bahwa kebudayaan

3 Ibid. Lihat juga Tadjab, dkk., DimensiDimensi Studi Islam, op. cit., hlm. 306, dan juga Dedi Supriyadi, Sejarah Peradaban Islam, (Bandung: Pustaka Setia, 2008), hlm. 16.

${ }^{4}$ Tadjab, dkk,, Dimensi-Dimensi Studi Islam., op., cit., 199., hlm.,306

5 Parsudi Suparlan, Kata Pengantar dalam Roland Robertson, Agama dalam Analisa dan Interpretasi Sosiologis, (Jakarta: Rajawali Press, 1988). 
adalah "manifestasi dari cara berfikir." 6

Pengertian yang lebih luas lagi dikemukakan oleh $\mathrm{Ki}$ Sarmidi Mangunkaro, yang menyatakan bahwa kebudayaan adalah segala yang merupakan (bersifat) hasil kerja jiwa manusia dalam arti yang seluasluasnya. Dikatakan lebih luas, karena hasil kerja jiwa manusia mencakup kerja periksa (pikiran, cipta), rasa (perasaan), karsa (kemauan), intuisi, imajinasi dan fakultas-fakultas rohani manusia lainnya. Hanya saja dalam definisi tersebut lebih ditekankan pada hasil kerja jiwa manusia, dan belum ditegaskan fungsi raga (jasmani) manusia dalam rangka penciptaan kebudayaan tersebut. Padahal totalitas manusia adalah mencakup jasmani dan rohani (jiwa), atau material substance dan spiritual substance secara seimbang, dan masing-masing mempunyai peranan dalam penciptaan kebudayaan. Sedangkan dalam Oxford Advanced Learners's Dictionary of Current English, diuraikan bahwa kata kebudayaan semakna dengan culture yang memiliki pengertian beragam. ${ }^{7}$

Berdasarkan

beberapa

pengertian culture di atas dapat

${ }_{7}^{6}$ S.Takdir Alisyahbana, ... op.cit., hlm., 80

AS. Hornby, Oxford Advanced Learners's Dictionary of Currrenl English. Oxford University Press, Great Britain, 1974., hlm., 80 dipahami bahwa kebudayaan adalah pembangunan yang didasarkan pada kekuatan manusia, baik pembangunan jiwa, pikiran, dan semangat melalui latihan dan pengalaman; bukti nyata pembangunan intelektual, seperti seni dan pengetahuan; atau perkembangan intelektual di antara budaya orang; bahwa kebudayaan adalah semua seni, kepercayaan institusi sosial, seperti karakteristik masyarakat, suku, dan sebagainya; mengolah pertanian sampai pada tingkat teknologi biologi bakteri.

Dalan tulisan Jaih Mubarok, definisi kebudayaan di antara yang terbaik sebagaimana dibuat oleh E. B. Taylor bahwa budaya adalah keseluruhan yang kompleks yang meliputi pengetahuan, kepercayaan, seni, moral, hukum, adat, serta kemampuan dan kebiasaan lain yang diperoleh manusia sebagai bagian dari masyarakat (that complex whole which includes knowledge, belief, art, morals, laws, custom and any other capabilities and habits acquired by man as a member of society). Secara singkat dan sederhana, sebagaimana dipahami secara umum, kebudayaan adalah "semua hasil karya, rasa, dan cipta masyarakat.

Karya masyarakat menghasilkan teknologi dan kebudayaan kebendaan (material 
culture) yang diperlukan oleh manusia untuk menguasai alam sekitarnya, agar kekuatan serta hasilnya dapat digunakan untuk keperluan masyarakat. Rasa yang meliputi jiwa manusia, mewujudkan segala kaidah dan nilai-nilai sosial yang perlu untuk mengatur masalahmasalah kemasyarakatan dalam arti yang luas. Agama, ideologi, kebatinan, dan kesenian yang merupakan hasil ekspil jiwa manusia yang hidup sebagai anggota masyarakat, termasuk di dalamnya.

Berdasarkan uraian di atas, Muhaimin, dkk menjelaskan bahwa ada beberapa hal yang patut digaris bawahi dari definisi-definisi tersebut, yaitu:

a. Kebudayaan adalah man-made atau karya/ciptaan manusia;

b. Yang menjadi bahan .kebudayaan adalah alam, baik bahan alam yang ada pada diri manusia maupun bahan alam yang terdapat di luar diri manusia;

c. Yang dijadikan alat penciptaan kebudayaan adalah jiwa dan raga (jasmani) manusia. Termasuk ke dalam jiwa adalah: periksa (pikiran, cipta), rasa (perasaan), karsa (kemauan), intuisi, imagi-nasi dan bagian-bagian rohani manusia lainnya; d. Ruang lingkup kebudayaan meliputi; segala aspek kehidupan (hidup rohaniah) dan penghidupan (hidup jasmaniah) manusia;

e. Pada garis besarnya kebudayaan dapat dibedakan atas kebudayaan immateri dan kebudayaan materi;

f. Tujuan kebudayaan adalah untuk kesempurnaan dan kesejahteraan manusia, baik sebagai individu maupun masyarakat, atau individu dan masyarakat sekaligus.

g. Kebudayaan merupakan jawaban atas tantangan, tuntutan dan dorongan intra diri manusia dan dari ekstra diri manusia; dan

h. Kebudayaan itu dapat diwariskan dan- diwarisi melalui proses pendidikan dan kebudayaan. $^{8}$

Kebudayaan setiap bangsa atau masyarakat terdiri atas unsur-unsur besar dan unsur-unsur kecil yang merupakan bagian dari suatu kebutuhan yang tidak dapal dipisahkan. Unsur-unsur kebudayaan dalam pandangan Malinowski sebagaimana dikutip oleh Koko Abdul Kodir adalah: a) Sistem norma; b) Organisasi ekonomi; c) Alat-alat dan lembaga atau petugas

\section{${ }^{8}$ Ibid.}


pendidikan; dan d) Organisasi kekuatan. $^{9}$

Lebih lanjut Koko Abdul Kodir menjelaskan bahwa unsur kebudayaan tersebut dapat dijabarkan lagi dalam unsur-unsur yang lebih kecil. Ralph Linton menyebutkannya sebagai cultural activity. Misalnya, cultural universal pencarian hidup ekonomi, antara lain mencakup kegiatan pertanian, peternakan, sistem produksi, dan sistem distribusi. Kegiatan kebudayaan pertanian dapat menjadi unsur lebih kecil yang disebut trait complex, seperti dalam pertanian misalnya, meliputi unsur irigasi, sistem pengelolaan tanah dengan bajak dan sistem hak milik tanah. ${ }^{10}$

Kebudayaan merupakan hasil karya, cara, dan cita-cita masyarakat yang memiliki unsur-unsur tingkat dan kegunaan. Pada prinsipnya, kebudayaan berfungsi selama para anggota masyarakat menerimanya sebagai petunjuk perilaku yang pantas.

Dalam melindungi dirinya, manusia menciptakan kaidah-kaidah yang pada hakikatnya merupakan petunjuk tentang cara bertindak dan berlaku dalam pergaulan hidup. Manusia selalu menciptakan kebiasaan bagi dirinya sendiri.
Kebiasaan tersebut dijadikan kebiasaan yang teratur oleh seseorang, kemudian dijadikan dasar bagi hubungan antar orang tertentu sehingga tingkah laku atau tindakan tersebut dapat diatur dan menimbulkan norma atau kaidah. Kaidah yang timbul dari rnasyarakat sesuai dengan kebutuhannya pada suatu saat dinamakan adat istiadat. Adat istiadat yang mempunyai akibat hukum disebut hukum adat.

Terkait hal itu, Koentjaraningrat mengemukakan adanya tiga (3) wujud dari kebudayaan, yaitu: a) Wujud kebudayaan sebagai suatu kompleks; b) Wujud kebudayaan sebagai suatu kompleks aktivitas kelakuan berpola dari manusia dalam masyarakat; dan c) Wujud kebudayaan sebagai bendabenda hasil karya manusia. ${ }^{11}$

Dalam penjelasan lain Koentjaraningrat, juga menyebutkan tiga wujud kebudayaan, yaitu: (1) wujud ideal, yaitu wujud kebudayaan sebagai suatu kompleks ide, gagasan, nilai-nilai, norma-norma, peraturan, dan sebagainya, (2) wujud kelakuan, yaitu wujud kebudayaan sebagai suatu kompleks aktivitas kelakuan berpola dari manusia dalam masyarakat, dan (3) wujud benda,

\footnotetext{
${ }^{11}$ Tadjab, dkk,, Dimensi-Dimensi Studi Islam., op., cit., 199., hlm.,307
}

\footnotetext{
${ }^{9}$ Koko Abdul Kodir. Metodologi Studi Islam., op., cit., hlm., 81

${ }^{10}$ Ibid.,
} 
yaitu wujud kebudayaan sebagai benda-benda hasil karya. ${ }^{12}$

Mengenai isi atau ruang lingkup kebudayaan itu adalah luas sekali, mencakup segala aspek kehidupan (hidup rohaniah) dan penghidupan (hidup jasmaniah) manusia. Hanya saja ada ahli yang memasukkan agama sebagai salah satu isi kebudayaan. Hal ini tentu merupakan persoalan tersendiri yang perlu didiskusikan. ${ }^{13}$

Dalam konteks ini, kebudayaan dan peradaban seringkali dianggap sebagai hal yang sama, padahal berbeda. Jika kebudayaan adalah bentuk ungkapan tentang semangat mendalam suatu masyarakat, maka manifestasi-manifestasi kemajuan mekanis dan teknologisnya lebih berkaitan dengan peradaban. Kalau kebudayaan lebih banyak direfleksikan dalam seni, sastra, religi (agama), dan moral, maka peradaban lebih terefleksi dalam politik, ekonomi, dan teknologi ${ }^{14}$

2. Islam

Pengertian Islam menurut pendapat Rosihan Anwar, dkk dapat dibedah dari dua aspek, yaitu aspek

${ }^{12}$ Dedi Supriyadi. Sejarah Peradaban Islam., op., cit., hlm., 18

${ }^{13}$ Tadjab, dkk,, Dimensi-Dimensi Studi Islam., op., cit., hlm., 308

${ }^{14}$ Dedi Supriyadi. Sejarah Peradaban Islam., op., cit., hlm., 18 kebahasaan dan aspek peristilahan. Dari segi kebahasaan, Islam berasal dari bahasa Arab, yaitu dari kata salima yang mengandung arti selamat 'sentosa, dan damai. Dari kata salima selanjutnya diubah menjadi bentuk aslama yang berarti berserah diri masuk dalam kedamaian. Oleh sebab itu, orang yang berserah diri, patuh, dan taat kepada Allah SWT. disebut sebagai orang Muslim. Dari uraian tersebut, dapat ditarik kesimpulan bahwa kata Islam dari segi kebahasaan mengandung arti patuh, tunduk, taat, dan berserah diri kepada Allah SWT. dalam upaya mencari keselamatan dan kebahagiaan hidup di dunia dan akhirat. Hal itu dilakukan atas kesadaran dan kemauan diri sendiri, bukan paksaan atau berpura-pura, melainkan sebagai panggilan dari fitrah dirinya sebagai makhluk yang sejak dalam kandungan telah menyatakan patuh dan tunduk kepada Allah. ${ }^{15}$

Adapun pengertian Islam dari segi istilah, banyak ahli yang mendefinisikannya. Harun Nasution mengatakan bahwa Islam menurut istilah (Islam sebagai agama) adalah agama yang ajaran-ajarannya diwahyukan Tuhan kepada masyarakat manusia melalui Nabi Muhammad SAW. sebagai Rasul.

\footnotetext{
${ }^{15}$ Risihon Anwar, dkk., Pengantar Studi Islam., Bandung : Pustaka Setia., 2014., hlm., 13
} 
Islam pada hakikatnya membawa ajaran-ajaran yang bukan hanya mengenal satu segi, tetapi mengenal berbagai segi dari kehidupan manusia. ${ }^{16}$ Sementara itu, Maulana Muhammad Ali mengatakan bahwa Islam adalah agama perdamaian dan dua ajaran pokoknya, yaitu keesaan Allah dan kesatuan atau persaudaraan umat manusia menjadi bukti nyata bahwa agama Islam selaras dengan namanya. Islam bukan saja dikatakan sebagai agama seluruh Nabi Allah, sebagaimana tersebut dalam Al-Quran, melainkan pula pada segala sesuatu yang secara tak sadar tunduk sepenuhnya pada undang-undang Allah. ${ }^{17}$

Apabila meneliti sumber kepustakaan Islam yang ditulis oleh para cendekiawan atau para ulama, kita akan mengetahui bahwa ajaranajaran Islam memiliki karakteristik yang khas, yang berbeda dari ajaranajaran agama Iainnya. Ali Anwar Yusuf menyebutkan bahwa karakteristik ajaran Islam itu: ${ }^{18}$

\section{a. Komprehensif}

Walaupun umat Islam itu berbeda-beda bangsa dan berlainan suku, dalam menghadapi asas-asas yang umum, umat Islam bersatu

16 Harun Nasution, Islam Ditinjau dari Berbagai Aspeknya, UI Press, Jakarta, 1985, hlm. 24.

${ }_{17}^{17} \mathrm{http}: / /$ www.percikaniman.org.

18 Rosihon Anwar, dkk., Pengantar Studi Islam., op. cit., hlm. 145-146. padu untuk mengamalkan asas-asas tersebut.

\section{b. Moderat}

Islam memenuhi jalan tengah, jalan yang imbang, tidak berat ke kanan untuk mementingkan kejiwaan (rohani) dan tidak berat ke kiri untuk mementingkan kebendaan (jasmani). Inilah yang diistilahkan dengan teori wasathiyah, yakni menyelaraskan antara kenyataan dan fakta dengan ideal dan cita-cita.

\section{c. Dinamis}

Ajaran Islam mempunyai kemampuan bergerak dan berkembang. mempunyai daya hidup, dapat membentuk diri sesuai dengan perkembangan dan kemajuan ajaran Islam terpencar dari sumber yang luar dan dalam, yaitu Islam yang memberikan sejumlah hukum positif yang dapat dipergunakan untuk segenap masa dan tempat.

\section{d. Universal}

Ajaran Islam tidak ditujukan kepada suatu kelompok atau bangsa tertentu, melainkan sebagai rahmatan lil 'alamin, sesuai dengan misi yang diemban oleh Rasulullah SAW. Ajaran Islam diturunkan untuk dijadikan pedoman hidup seluruh manusia untuk rneraih kebahagiaan di dunia dan di akhirat. Dengan demikian. hukum Islam bersifal universal, untuk seluruh umat manusia di muka bumi dan 
dapat diberlakukan di setiap bangsa dan negara.

e. Elastis dan fleksibel

Ajaran Islam berisi disiplindisiplin yang dibebankan kepada setiap individu. Disiplin tersebut wajib ditunaikan dan orang yang melanggarnya akan berdosa. Meskipun jalurnya sudah ada membentang. dalam keadaan tertentu terdapat kelonggaran (rukhshah). Kelonggaran-kelonggaran tersebut menunjukkan bahwa ajaran Islam bersifat elastis, luwes, dan manusiawi. Demikian pula, adanya qiyas, ijtihad, istihsan, dan mashlahih mursalah, merupakan salah satu jalan keluar dari kesempitan.

\section{f. Tidak memberatkan}

Ajaran Islam tidak pernah membebani seseorang sampai melampaui kadar kemampuannya karena Islam mempunyai misi sebagai rahmatan bagi manusia. Islam datang untuk membebaskan manusia dari segala sesuatu yang memberatkannya.

\section{g. Graduasi (berangsur-angsur)} Ajaran-ajaran Islam yang diberikan kepada manusia secara psikologis sesuai dengan fitrahnya sendiri. Apabila ajaran-ajaran tersebut diturunkan sekaligus, sangat sulit bagi manusia untuk menjalankannya. Oleh karena itu, Allah menurunkan ajaran Islam secara berangsur-angsur, agar manusia melaksanakannya dengan sebaik-baiknya.

h. Sesuai dengan fitrah manusia Ajaran Islam sesuai dengan fitrah manusia, dalam arti sesuai dengan watak hakiki dan asli yang dimiliki oleh manusia. Dengan demikian. ajaran Islam yang sesuai dengan fitrah manusia memberikan keterangan yang pasti tentang kepercayaan asli dan hakiki yang ada dalam diri manusia. Artinya, kondisi awal ciptaan manusia memiliki potensi untuk selalu mengetahui dan cenderung pada kebenaran, yang dalam Al-Quran disebut dengan hanif.

\section{i. Argumentatiffilosofis}

Ajaran Islam merupakan ajaran yang argumentatif; tidak cukup dalam menetapkan persoalanpersoalan dengan mengandalkan doktrin lugas dan instruksi keras. Demikian pula. tidak cukup sekadar berdialog dengan hati dan perasaan serta mengandalkannya untuk menjadi dasar pedoman. Akan tetapi, harus dapat mengikuti dan menguasai segala persoalan dengan disertai alasan yang kuat dan argumentasi yang akurat. ${ }^{19}$

\section{Kebudayaan Islam}

${ }^{19}$ Ali Anwar Yusuf, Studi Agama Islam untuk Perguruan Tinggi, Pustaka Setia, Bandung, 2003, hlm., 36-38. 
Kebudayaan Islam menurut pendapat Sidi Gazalba adalah "cara berfikir dan cara merasa taqwa yang menyatakan diri dalam seluruh segi kehidupan sekumpulan manusia yang membentuk masyarakat", atau dapat disarikan sebagai "cara hidup taqwa". Cara hidup taqwa yaitu menempuh jalan syariat, menjalankan suruhan serta menghentikan larangan. Syariat mengikatkan/ mempertalikan muslim kepada prinsip-prinsip tertentu yang digariskan oleh Al-Qur'an dan assunnah/hadits (naqal). Karena itu akal dalam kegiatnnya mengatur kehidupan merujuk kepada naqal, dengan kata lain gerak atau kegiatan kebudayaan itu memang dari akal, tetapi asas gerak itu atau prinsip yang dipegangi akal dalam kegiatannya adalah dari naqal. Dari asas yang ditentukan dan digariskan oleh naqal itu kemudian adalah menentukan cara pelaksanaannya. Karena itu yang merupakan karya manusia dalam kebudayaan Islam ialah cara pelaksanaan yang bersifat dinamik, sedangkan prinsipprinsipnya dari Allah dan bersifat serba tetap. ${ }^{20}$

Nilai asas (root values) prinsip-prinsip itu digariskan oleh syariat, ada nilai yang baik (wajib); nilai setengah baik (sunnat); nilai

${ }^{20}$ Tadjab, dkk,, Dimensi-Dimensi Studi Islam., op., cit., 199., hlm.,312 netral yakni baik tidak dan burukpun tidak (jaiz/mubah); ada nilai setengah buruk (makruh); dan ada pula nilai buruk (haram). Cara pelaksanaan prinsip-prinsip itu difikirkan oleh ijtihad (instrumental valuesnya) dan dikerjakan oleh tangan, sedangkan kemauan untuk mengerjakan itu dipancarkan oleh taqwa. ${ }^{21}$ Namun demikian kita harus mampu mendudukkan secara proporsional, mana yang termasuk nilai asal (root values) dan mana pula yang termasuk cara pelaksanaan (instrumental values). Sebab kadangkala ada sesuatu yang nampaknya merupakan cara pelaksanaan, tetapi yang sebenarnya adalah nilai asas.

Endang Saifuddim Anshari mengkategorikan kebudayaan muslim ke dalam dua bagian, yaitu: (1) Kebudayaan muslim yang Islami, yakni kebudayaan karya budaya muslim yang commited pada alislam; dan (2) kebudayaan muslim yang tidak Islami, yakni kebudayaan muslim yang tidak comitted pada alIslam. Muslim yang committed pada al-Islam ialah muslim yang mengimani (menghayati), mengilmui, mengamalkan, dan mendakwahkan Islam, serta sabar dalam ber Islam. Namun demikian Endang Saifuddin Anshari juga memper-masalahkan tentang

${ }^{21}$ Ibid., hlm., 312 
"apakah mungkin tercipta kebudayaan yang seratus persen Islami di dunia ini"? Dalam hal ini dia telah menjelaskan bahwa kebudayaan itu karya manusia, sedangkan di dunia ini tidak ada seorang pun (kecuali Rasul) yang sempurna. Karena itu tidak mungkin mengharapkan sesuatu kesempurnaan dari sesuatu yang tidak seratus persen sempurna. Tercapainya kesempurnaan adalah tujuan ideal manusia, namun bukan tugas manusia. Tugas manusia bukan sampai pada kesempurnaan, melainkan bergerak, berupaya dan berusaha sekuat tenaga untuk mencapainya.

Oleh sebab itu, kebudayaan muslim nilainya tidak mutlak, terikat oleh ruang dan waktu, terbuka untuk revisi, koreksi dan reevaluasi. Setiap muslim berhak untuk berimprovisasi (melakukan sesuatu) dalam mengkulturkan natur dan dalam mengislamkan kultur sesuai dengan tuntutan alam dan zamannya, yang masing-masing bisa berbeda dengan lainnya. Apabila kebudayaan muslim sudah dibakukan, yang nilai kemutlakannya disamakan dengan al-Islam, maka akan timbul kemandekan kebudayaan yang pada giliran selanjutnya akan menjadi barang antik yang tidak berguna lagi, serta daya kreativitasnya akan terhenti. ${ }^{22}$

Dengan memperhatikan pendapat Endang Saifuddin Anshari tersebut, yakni bahwa ada kebudayaan muslim Islami (committed pada al-Islam), dan ada kebudayaan muslim yang tidak Islami (tidak committed pada alIslam), berakibat memaksa kita untuk menyeleksi kembali hasil karya (budaya) muslim pada masa keemasan/kejayaan-nya. Jika buah/hasil karya itu berasal dari muslim yang tidak committed pada al-Islam, maka haruslah dikeluarkan dari kebudayaan dan peradapan Islam.

Lebih lanjut, Clemmer (1969: 221) menyatakan adanya revitalisasi dalam kebudayaan, yang bertujuan mengonstruksi kebudayaan yang lebih dapat memuaskan pelaku budaya itu. Revitalisasi tersebut terjadi karena adanya resistensi antara upaya mempertahankan kebudayaan yang selama ini dianggap mapan dengan usaha mengadopsi perubahan budaya. Jadi, dapat dikatakan bahwa konstruksi kebudayaan Islam mengandung pengertian adanya produk budaya yang dihasilkan oleh pikiran dan

${ }^{22}$ Tadjab, dkk,, Dimensi-Dimensi Studi Islam., Surabaya : Karya Aditama., 1994., hlm., 313314 
tindakan para penganutnya dalam proses produksi budaya keagamaan.

Dalam keadaan pengaruh yang kuat terhadap sistem-sistem nilai yang ada pada kebudayaan masyarakat yang bersangkutan (umat Islam), sistem-sistem nilai dari kebudayaan mereka terwujud dalam simbol suci yang maknanya bersumber pada ajaran agama Islam yang menjadi kerangka acuannya. Secara struktural-fungsional, agama melayani kebutuhan manusia untuk mencari kebenaran, mengatasi, dan menetralkan berbagai hal buruk dalam kehidupan mereka.

Dengan merujuk pada Islam sebagai sistem kebudayaan, jelas bahwa sistem kebudayaan Islam diciptakan dalam kaitannya dengan proses reproduksi sosial. Dari sini, studi Islam sebagai sistem kebudayaan memiliki asumsi bahwa simbol-simbol Islam -sebagai bahan dari kebudayaan Islam dalam kapasitasnya sebagai agama dipengaruhi oleh realitas, melalui aksi manusianya yang tepat dalam membentuk realitas. Dengan demikian, agama Islam juga dapat menjadi inti dari sistem-sistem nilai yang ada dalam kebudayaan masyarakat yang bersangkutan sebagai pendorong, penggerak, dan pengontrol bagi tindakan-tindakan anggota masyarakatnya untuk tetap berjalan sesuai dengan nilai-nilai kebudayaan yang tercakup dalam ajaran agama Islam. ${ }^{23}$

Kebudayaan Islam itu mempunyai 3 (tiga) komponen, yaitu: sistem nilainya; sistem pengetahuan; dan sistem simbol. Dan kita tidak perlu membicara-kan apakah budaya islam itu Islami atau tidak Islami, sebab hal ini tidak lagi menanyakan masalah kebudayaan. Dalam arti bahwa budaya itu Islami atau tidak, adalah di luar wewenang atau di luar budaya itu sendiri, karena hal itu berarti kita kembali ke hal-hal yang bersifat normatif. ${ }^{24}$

Ciri-ciri kebudayaan Islam (muslim) menurut pendapat Nourouzzaman Shiddiqi adalah:

a. Bernafaskan tauhid, karena tauhidlah yang menjadi pokok ajaran Islam;

b. Hasil buah pikir dan pengolahannya adaiah dimaksudkan untuk meningkatkan kesejahteraan dan membahagiakan umat manusia. Sebab Islam diturunkan dan Nabi SAW diutus adalah untuk membawa rahmat bagi semesta alam. Di samping itu, manusia dijadikan sebagai khalifah Allah di bumi dengan dibebani tugas untuk

\footnotetext{
${ }^{23}$ Ibid., hlm., 87

${ }^{24}$ Tadjab, dkk,, Dimensi-Dimensi Studi Islam., op., cit., 310
} 
menjaga keindahan ciptaan Allah ini.

Karena itulah produk budaya yang membawa kepada malapetaka dan kehancuran, jelas tidak termasuk kebudayaan yang bercirikan Islam. ${ }^{25}$

Setelah dikemukakan beberpa pandangan para ahli ataupun ciri-ciri kebudayaan Islam (muslim) tersebut, maka menurut pandangan Muhaimin dkk., ada satu hal yang disepakati oleh mereka, yaitu bahwa berkembangnya kebudayaan menurut pandangan Islam bukanlah value-free (bebas nilai), tetapi justeru value-bound (terikat oleh nilai). Keterikatan terhadap nilai tersebut bukan hanya terbatas pada wilayah nilai insani, tetapi juga menembus pada nilai llahi sebagai pusat nilai, yakni keimanan kepada Allah, dan iman ini akan mewarnai semua aspek kehidupan atau mempengaruhi nilainilai lain. ${ }^{26}$

\section{Islam Mendorong kepada Kebudayaan}

Pada uraian terdahulu telah dijelaskan bahwa agama samawi (revealed religion/agama wahyu) bukanlah termasuk kebudayaan, karena ia bukan produk manusia, tetapi dari Tuhan Yang Maha Esa (Allah) yang telah menurunkan wahyu kepada utusan-Nya, untuk

\footnotetext{
${ }^{25}$ Ibid., hlm., 313-314

${ }^{26}$ Ibid., hlm., 314
}

disebarkan kepada umat manusia. Agama Islam termasuk agama samawi (agama wahyu), sehingga tidak termasuk kebudayaan. Namun demikian agama Islam telah mendorong para pemelukknya untuk menciptakan kebudayaan dengan berbagai seginya. Dorongan tersebut dapat dikaji dari ajaran dasarnya sebagai berikut:

a. Islam menghormati akal manusia, meletakkan akal manusia pada tempat yang terhormat dan menyuruh manusia mempergunakan akalnya untuk memeriksa dan memikirkan keadaan alam, di samping dzikir kepada Allah Penciptanya. Hal ini dapat difahami dari firmanNya dalam Q.S. Ali Imran ayat 190-191.

b. Agama Islam mewajibkan kepada tiap-tiap pemelukknya, baik laki-laki maupun perempuan, untuk mencari dan menuntut ilmu, sebagaimana dapat difahami dari firman Allah Q.S. Al-Mujadilah ayat 11. Dan hadits Nabi SAW. "menuntut ilmu wajib bagi setiap orang Islam", serta hadits Nabi SAW.: "Carilah ilmu walaupun di negeri Cina".

c. Agama Islam melarang orang bertaqlid buta, menerima sesuatu tanpa diperiksa lebih dahulu, walau dari ibu bapak 
dan nenek moyang sekalipun. Sebagaimana firman Allah dalam Q.S. al-lsra' ayat 36.

d. Agama Islam juga mendorong dan menggalakkan para pemeluknya agar selalu menggali hal-hal yang baru atau mengadakan barang yang belum ada, merintis jalan yang belum diternpuh serta membuat inisiatif dalam hal keduniaan yang memberi manfaat kepada masyarakat. Hal ini dapat difahami dari iirnan Allah dalam Q.S. Alam Nasyrah ayat 7-8, dan hadits Nabi SAW.: "Barang siapa yang berinisiatif (memulai suatu cara keduniaan) yang baik, maka baginya pahala sebanyak pahala untuk orang yang langsung melaksanakannya itu sampai hari kiamat.

e. Agama Islam juga menyuruh para pemeluknya untuk mencari keridlaan Allah dalam semua nikmat yang telah diterimanya dan menyuruh mempergunakan hak-haknya atas keduniaan dalam pimpinan dan aturan agama. Sebagaimana firman Allah dalam Q.S. al-Qashash ayat 77.

f. Agama

Islam menganjurkan pemeluknya agar pergi meninggalkan kampung halamannya, berjalan ke daerah/negeri lain untuk menjalin silaturrahmi (komunikasi) dengan bangsa atau golongan lain, saling bertukar fikiran, pengetahuan dan pandangan. Sebagaimana dapat difahami dari firman Allah dalam Q.S. Al-Hajj: ayat 46.

g. Agama Islam juga menyuruh para pemeluknya untuk memeriksa dan menerima kebenaran dari mana dan siapapun datangnya, dengan catatan harus melalui proses seleksi, sehingga dapat menemukan ide, gagasan, teori atau pandangan yang sesuai dengan petunjukNya. Sebagaimana dapat difahami dari firman Nya dalam Q.S. alZumar ayat 17-18.

Sebenarnya masih banyak ajaran-ajaran Allah dan rasulNnya yang membicarakan masalah tersebut, tetapi dari ketujuh point tersebut sudah dapat difahami bahwa ajaran agama Islam memang benarbenar mendorong para pemeluknya dan atau menyuruh mereka untuk menciptakan kebudayaan dalam berbagai seginya. ${ }^{27}$

\footnotetext{
${ }^{27}$ Tadjab, dkk,, Dimensi-Dimensi Studi Islam., op., cit., hlm., 311
} 


\section{E. Penutup}

Islam dengan ajarannya yang menempatkan akal manusia pada tempat yang terhormat telah terbukti betapa manusia ketika menggunakan akalnya dengan baik dan benar, maka manusia mampu meraih kemajuan, baik itu kemajuan dalam bidang peradaban maupun kemajuan dalam bidang kebudayaan. Begitupun dengan penggunaan akalnya manusia telah mampu menciptakan sanis dan teknologi yang tinggi yang dapat membuat manusia menjadi makhluk yang benar-bnar maju. Dan mampu menguasai dunia bahkan mampu menginjakkan kakinya di Bulan.

\section{Daftar Pustaka}

Yusuf, Ali Anwar. 2003. Studi Agama Islam untuk Perguruan Tinggi, Bandung: Pustaka Setia, 2003.

Hornby, AS. 1974. Oxford Advanced Learners's Dictionary of Currenl English. Great Britain: Oxford University Press.
Supriyadi, Dedi. 2008. Sejarah Peradaban Islam. Bandung: Pustaka Setia.

Nasution, Harun. 1985. Islam Ditinjau dari Berbagai Aspeknya. Jakarta: UI Press.

http://www.percikaniman.org.

Kodir, Koko Abdul. 2012. Metodologi Studi Islam. Bandung: Pustaka Setia.

Suparlan, Parsudi. Kata Pengantar dalam Roland Robertson. 1988. Agama dalam analisa dan Interpretasi Sosiologis. Jakarta: Rajawali Press.

Anwar, Rosihon dkk. 2014. Pengantar Studi Islam. Bandung: Pustaka Setia.

Tadjab, dkk. 1994. Dimensi-Dimensi Studi Islam. Surabaya: Karya Aditama.

Victor W, Turner. 1967. The Forest Of Symbols. Ithaca: Cornel University Press. 